\title{
Romero, Araripe, Veríssimo e a recepção crítica do romance machadiano
}

\author{
H ÉLIO de SEIXAS GUIMARÃES
}

$\mathrm{N}$

O TERRENO DA CRÍTICA regular e militante, que no Brasil se formou e tomou corpo em paralelo e em torno da produção de M achado de Assis, sobretudo dos romances, publicados entre 1872 e 1908, é indiscutível a importância de Sílvio Romero, Araripe J r. e J osé Veríssimo. M uitos outros contemporâneos de $M$ achado reagiram à sua obra à medida que os romances eram publicados. Entre eles, constam nomes que esmaeceram com o tempo, como os deU rbano D uarte, J osé C arlos R odrigues, Augusto Fausto de Sousa e M agalhães de Azeredo; outros que ficaram obscurecidos sob pseudônimos, tais como Araucarius, Abdiel e José Anastácio; e um terceiro grupo formado por nomes que permanecem na história da literatura, caso de M edeiros e Albuquerque, O lavo Bilac e Raul Pompéia, autores de vôo próprio e talvez por isso mesmo pouco lembrados entre os primeiros leitores de $M$ achado de Assis.

M as foi a tríade formada por Romero, A raripe e Veríssimo que respondeu à obra machadiana de maneira mais variada e sistemática e a cujas críticas o escritor também reagiu, ativamente ou pelo silêncio eloqüente. $\mathrm{E} m$ alguns casos, $\mathrm{M}$ achado incorporou ao romance questões colocadas por esses primeiros leitores, pondo em prática a dialética entre produção literária e atividade crítica, desejada e expressa por ele nas décadas de 1860 e 1870 em textos como “O ideal do crítico" (1865) e "I nstinto de N acionalidade" (1873).

D eterminismo, evolucionismo, positivismo, romantismo e naturalismo essas as palavras-chave que, com suas derivações e ramificações, formariam a constelação de idéias e dariam as balizas para a atividade crítica no Brasil do século XIX. M as a freqüentação dos grandes sistemas e a invocação dos grandes nomes Taine, D arwin, Comte, Chateaubriand e Zola - contribuiu tanto para imprimir o tão decantado rigor científico ao estudo da literatura quanto para levantar cortinas de fumaça em torno da pura opinião, da interpretação impressionista, da mera e velha disputa das vaidades, que alimentaram célebres polêmicas, com suas acusações, réplicas, tréplicas e ódios mortais ${ }^{1}$.

O s três grandes da crítica machadiana não fugiram a essa conjunção, como se nota ao estudar a reação que tiveram diante do caso M achado de Assis. É disso que trato aqui, chamando a atenção, a partir do exame dessa produção crítica de 
primeira hora, para: 1) os desafios e mudanças de parâmetro que uma obra literária desse porte coloca para a crítica, desestabilizando as concepções do literário e pondo em xeque a aplicação rígida de teorias e doutrinas; e 2) 0 aparecimento de questões, como a do humorismo e da representatividade nacional do romance machadiano, que teriam desdobramentos importantes em estudos futuros.

Araripe J r. (1848-1911) e Sílvio Romero (1851-1914) são rigorosamente contemporâneos e entram em cena quase simultaneamente, no início da década de 1870, quando da publicação de Falenase C ontosFluminen ses. Por esse período, ainda eram companheiros em Recife e editavam juntos $A$ crença, jornal em que Romero publicou seu primeiro artigo sobre Machado de Assis. José Veríssimo (1857-1916), um pouco mais novo, entrará em campo só em 1892, por ocasião do aparecimento, em volume, de QuincasBorba. A tríade, portanto, estará formada com a publicação desse livro. É justamente nesse momento que a crítica machadiana toma corpo, não só em termos numéricos, por ter sido esse o romance de $\mathrm{M}$ achado que produziu reação crítica mais volumosa, mas também em termos qualitativos, já que so bre o livro também escreveram M agalhães de Azeredo, José A nastácio (provável pseudônimo de Teófilo G uimarães) e Artur de Azevedo.

A linguagem empregada nos artigos dedicados ao romance revelam a distância existente entre o texto de $\mathrm{M}$ achado e as expectativas da crítica. U m resenhista qualificou o livro de "um brilhante demais engastado no diadema da literatura brasileira”, "um cálix de licor finíssimo que a gente prova e sorve de um trago"2. O utro, numa série de artigos elogiosos a Brás Cubas e Quincas Borba, referiu-se ao humorismo do escritor como uma "flor doentia da experiência e da desilusão, que semelha um goivo de sepulcro abrindo-se numa jarra de porcelana de Sèvres, sobre um piano donde se evolam acordes de polcas alegres, no turbilhão doido de um baile de duendes" ${ }^{3}$. A té mesmo J osé Veríssimo, quase sempre tão comedido e sóbrio, exorbitou nos adjetivos ao dizer que livros como os de M achado de Assis " confortam-nos al gumas horas como o doce perfume de uma flor rara ou a sombra fofa de uma copa de árvore em meio de longo caminho árido"4.

É tão inútil quanto tentador imaginar as expressões no rosto do escritor diante de tais elogios. M as dez anos depois da perplexidade e frieza que marcaram a recepção de Brás Cubas, definido por Araripe como "o livro mais esquisito de quantos se têm publicado em língua portuguesa" ${ }^{5}$, e por R omero como "bolorenta pamonha literária" ${ }^{6}$, Quincas Borba, de algum modo, esclarecia o que havia de proposital no romance anterior. O livro trazia de volta a prosa estranha e corrosiva de 1880-1881, que a crítica passaria a distinguir, tanto em relação à produção literária brasileira como em relação à obra anterior de $\mathrm{M}$ achado, pelo humori smo. 0 que era esse humour e de que modo ele distanciava $M$ achado do caráter nacional, filiando-o a tradições estrangeiras, e a quais tradições - esses serão assuntos recorrentes e motivos de disputa entre a crítica contemporânea, com desdobramentos também na crítica póstuma. 
É em torno da recepção de QuincasBorba e da questão do humorismo que procurarei definir as diferentes posições de Romero, Araripe e Veríssimo diante da obra de M achado.

\section{R omero: o escritor anacrônico}

Apesar de ser voz dissonante e isolada, foi em torno da opinião quase sempre injusta e destrambelhada de Sílvio Romero que se formou o que poderíamos definir como a crítica coeva de $M$ achado de Assis. N as resenhas sobre Quincas Borba, Araripe respondia de forma velada e Veríssimo reagia explicitamentea Sílvio Romero, que em 1882 desancara o autor das M emórias Póstumas, chamando-o de "tênia literária", "ente infeliz", acusando-o de oportunista e anacrônico, por não ter forças de romper com o passado e por equilibrar-se comodamente numa combinação de classicismo e romantismo. $M$ ais recentemente, Romero excluíra M achado de Assis da sua H istória da Literatura Brasileira, publicada em

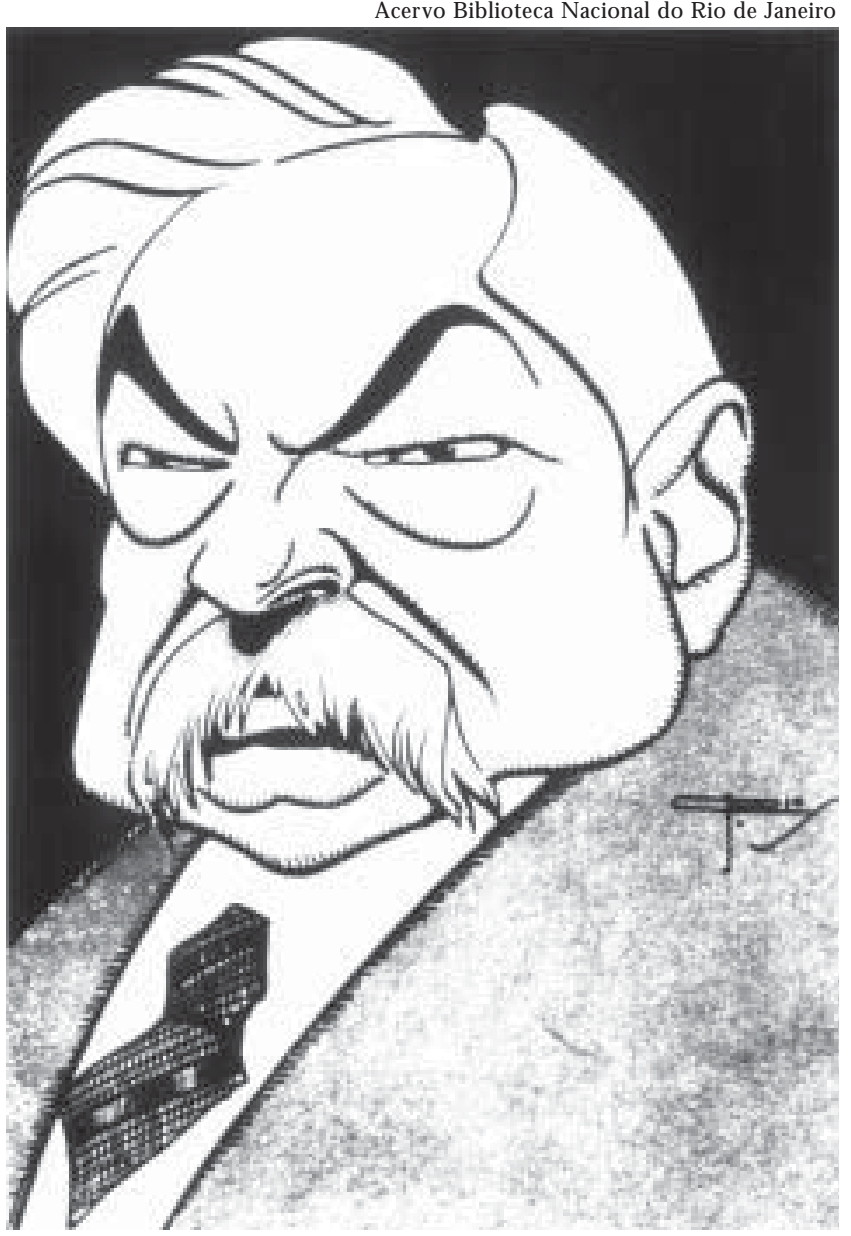

Sílvio R omero, reprodução do desen ho de J. Carlos. 1888. Por outro lado, a reação em linhas gerais entusiástica a Quincas Borba serviria de estímulo e daria munição para Sílvio Romero produzir seu ataque final a $M$ achado, não mais por meio de artigos na imprensa, mas na forma de um livro, M achado de A ssis - estudo comparativo de Literatura Brasileira.

N essa obra da maturidade romeriana, espécie de súmula do seu antimachadianismo, Romero promete amainar a ferocidade dos seus ataques, mas não se emenda ("eu não recuo; não está nos meus hábitos recuar" ) e procura colocar $M$ achado contra seus críticos. D iz que estes em geral são falsos, pois em público elogiam o escritor como uma espécie de sestro, mas nas rodas literárias dizem coisas horríveis sobre ele, coisas que diz ter ouvido mas não vai contar, para não transformar sua crítica em bisbilhotice, e por serem coisas que talvez só coubessem 
nas suas memórias póstumas. 0 alvo não é apenas o homem M achado de Assis e/ ou sua obra, mas toda a crítica produzida até então, acusada de fetichista, retórica e idólatra. N ão se tratava, portanto, de petardos dirigidos a um desafeto, mas de uma guerra inteira, já que o objetivo não era apenas colocar M achado "em seu lugar" , mas desqualificar todos os críticos favoráveis a M achado, acusados de pedantes, insinceros, excessivamente indulgentes - os louvaminheiros de profissão.

D iante da amplitude do alvo, fica difícil falar em reação a aspectos determinados da obra de $M$ achado, mas de reação, ponto final, um dos sestros do reativíssimo Sílvio Romero, que se auto-intitulava "um justiceiro" e passou boa parte da vida tentando explicar a antipatia por M achado de Assis e exaltar a genialidade de Tobias Barreto. No livro de 1897, esse seu mestre da escola do Recife mais uma vez serve de termo de comparação para diminuir os talentos de $M$ achado de Assis como poeta, prosador e humorista. Ao longo de toda a carreira, Tobias Barreto foi a "clava de H ércules", o instrumento preferido na sua sanha de esbordoar os outros, como bem observou A raripe Júnior em "Sílvio Romero polemista”. Assim, pelos parâmetros críticos de Romero, Tobias Barreto encarnava a excelência, mas o prosador $M$ achado teria muito que aprender com Rui Barbosa, C amilo C astelo Branco, José do Patrocínio, Sales Torres-H omem, Latino Coelho, entre muitos outros.

0 motivo de tanto ódio? 0 estudo comparativo era a resposta, fermentada durante quase vinte anos, aos senões dirigidos à poesia de Romero em A nova geração, o famoso texto crítico de M achado de Assis, publicado em 1879. Romero, absoluto desconhecedor de sutilezas, deixa claro o revide já no primeiro parágrafo da introdução, ao afirmar que entre as singularidades das coisas literárias do B rasil está a constante e espontânea produção, por qualquer mocinho ou rapazelho (leia-se Machado, que na realidade era mais velho que Romero), de "novas gerações" : " das tais gerações novas, novíssimas, recentes, recentíssimas, modernas, moderníssimas, já passaram por nós, nada menos de duas dúzias!... Já se vê, portanto, que esta fertilidade não é coisa séria, e quem tiver bom senso deve opor embargos a tanta ligeireza" 7 .

Contra a ligeireza e a banalidade, Romero propõe o estudo de M achado de Assis “à luz de seu meio social, da influência de sua educação, de sua psicologia, de sua hereditariedade fisiológica e étnica, mostrando a formação, a orientação normal de seu talento" ${ }^{8}$. Partindo da idéia de que o escritor é um centro de força, que age como fator de diferenciação e progresso, e também uma resultante, efei to deum meio, devendo refletir a sociedade a que pertence, ele não pode ser muito mais nem muito menos do que determinaria sua origem fisiológica, social e nacional, ainda que possa evoluir. Por esses critérios, $M$ achado de Assis - pobre, pouco escolarizado, tímido, gago, mulato - e sua obra - de pouca exaltação patriótica, parco talento descritivo e baixo investimento na pintura da natureza local - eram uma consumada enciclopédia de negativas. E no que diz respeito à diferenciação e ao progresso, a obra de Machado representaria um enorme 
retrocesso, pelo apego aos modelos clássicos e românticos, modelos com os quais, por timidez e tibieza, o escritor não teria conseguido romper.

É no plano pessoal que o crítico centra fogo. Por exemplo, chamará a atenção para o fato de Machado de Assis não possuir diploma, ter instrução limitada, "de princípio demasiado parca", numa referência à origem pobre do escritor, o que teria feito dele um funcionário mediano, para não dizer medíocre. M as o grande problema de Sílvio Romero, para quem as questões de raça e miscigenação eram centrais na definição e na singularização da nacionalidade e, portanto, da literatura brasileira, está no fato de M achado, "genuíno representante da sub-raça brasileira cruzada", não se entregar "à sua condição de meridional e mestiço". Para Romero, isso é um tipo de afetação, quase uma impostura, com repercussões na obra, marcado pelo artificialismo, pelo isolamento e indiferença em relação ao meio, pelas costas voltadas à paisagem e ao povo brasileiro. As categorias centrais de raça e miscigenação deslizam com facilidade para os argumentos da animosidade com M achado, que não se enquadrava no papel previsto e, ato contínuo, era logo encaixado em outro estereótipo, o do mulato pernóstico, de modos afetados, afrancesados, incapaz de reconhecer sua condição de verdadeiro meridional e mestiço. $\mathrm{E} m$ alguns momentos, Romero parece não se conformar mesmo é com o fato de $M$ achado ter escrito o que escreveu sendo mulato, sem se perder no que chama de "moléstia da cor" , "nostal gia da al vura", "despeito contra os que gozam da superioridade da branquidade" 9 .

D iante dos ataques, L afayette R odrigues Pereira saiu em defesa do romancista. Entre janeiro e fevereiro de 1898, publicou quatro artigos no J ornal do Comércio, sob o pseudônimo de Labieno. N eles, refutava os ataques Romero, enfatizando principalmente as excelências do estilo do escritor. M achado, ao longo de to da a carreira muito sensível e atento à recepção de sua obra, escreveu uma carta de agradecimento ao conselheiro L afayette tão logo conheceu a identidade do autor das palavras de simpatia dirigidas a ele. No ano seguinte, os artigos foram reunidos no livro Vindiciae- O Sr. Sílvio R omero crítico e filósofo, que hoje talvez interesse mais como exemplo da retórica que regia a sociabilidade literária do tempo do que pelos juízos críticos ali expressos.

$M$ as por trás dos excessos de R omero, havia regras. Evolucionista convicto ( "meu pensamento em filosofia mudou do positivismo para o evolucionismo spencerista, chamado também por al guns agnosticismo evolucionista”, definiu), Romero aplicou os princípios de Spencer à obra de Machado não só para considerá-la anacrônica, mas para refutar a divisão da obra em duas fases, proposta por Veríssimo e aceita por Araripe Jr. Para Romero, não havia ruptura parcial nem completa entre Iaiá Garcia e Brás Cubas. Machado era desde o início um só, no pouco que havia nele de bom, e no muito de mau, já que nem a natureza e nem a psicologia normal se move em saltos. Sempre necessariamente do contra, freqüentemente se refere a M achado como o autor de $\mathrm{H}$ elena e Iaiá Garcia, e chega a declarar sua preferência pelos primeiros romances do 
escritor, em que o humorismo seria mais espontâneo e singelo, mais de acordo com a índole pacata do escritor, em contraste com o humorismo artificial, farfalhante e puramente imitativo adotado a partir de BrásC ubas.

Diante dos ataques, Lafayette Rodrigues Pereira saiu em defesa do romancista. Entre janeiro e fevereiro de 1898, publicou quatro artigos no J ornal doC omércio, sob o pseudônimo de L abieno. N eles, refutava os ataques de Romero, enfatizando principalmente as excelências do estilo do escritor. Machado, ao longo de to da a carreira muito sensível e atento à recepção de sua obra, escreveu uma carta de agradecimento ao conselheiro Lafayette tão logo conheceu a identidade do autor das palavras de simpatia dirigidas a ele. No ano seguinte, os artigos foram reunidos no livro Vindiciae- O Sr. Sílvio R omero crítico e filósofo, que hoje talvez interesse mais co mo exemplo da retórica que regia a sociabilidade literária do tempo do que pelos juízos críticos ali expressos.

M as por trás dos excessos de R omero, havia regras. 0 humorismo, apontado por Veríssimo como singularidade da prosa machadiana, era considerado por Romero como inadequado e artificial, por estar em desacordo com a psicologia, o temperamento e o caráter não só do escritor, mas da "nossa raça". H umorismo, pessimismo e ironia, que ao longo da década de 1890 já se tornavam palavras recorrentes da crítica machadiana, serão os alvos da sanha de Romero ao tratar do prosador. Daí a crítica ao estilo repetitivo e reiterativo, que vai chamar de tartamudeante, ao pessimismo implacável, que qualificará "de pacotilha", ao humo rismo desesperançado, que chamará de "afetado", e aos personagens pouco exemplares, como Brás C ubas e Q uincas Borba, tachados respectivamente como "adúltero enjoativo" e "lunático sensaborão".

0 ponto mais sensível de Romero, no entanto, parece estar no que ele atribui à impotência de $M$ achado, e de um certo grupo de românticos brasileiros, de tomar partido entre as grandes correntes filosóficas do século, assim enumeradas por Romero: materialismo, positivismo, evolucionismo, monismo transformístico, hartmmannismo. Para ele, parece insuportável o fato de $M$ achado de Assis, num país de caráter indefinido, onde o povo ainda nem sabia ler, ocupar-se de rir de muita coisa respeitável e sagrada, como as grandes teorias do século, sustentáculos do pensamento romeriano, dos quais $M$ achado faz troça por meio de $Q$ uincas B orba e Rubião. Espírito demolidor, mas paradoxalmente imbuído de ideais construtivos, Romero exaspera-se com o aspecto impalpável, a refração às classificações, o tom irreverente e a carga de negativismo que permeiam a obra machadiana, sobretudo a partir de BrásC ubas.

M uito afeito a partidos, escolas, métodos, correntes e doutrinas, balizas de que talvez precisasse desesperadamente para conter seu espírito bélico e atribuir ares de rigor científico ao que às vezes não passava de destempero, má-vontade e antipatia, é inegável o mérito de Romero na defesa de parâmetros mais ou menos fixos para a atividade crítica num momento em que a crítica literária raramente escapava da paráfrase ou do tom desbragadamente elogioso. Ele não estava 
completamente destituído de razão ao referir-se a críticos como “louvaminheiros de profissão", ou denunciar com indignação o isolamento e a baixa representatividade da produção literária, demolindo a ilusão romântica de que a literatura pudesse representar e ser representativa da nação - coisa que R omero, no entanto, desejava.

N o que se refere à prosa de M achado, não eram impertinentes os questionamentos que fazia sobre o tom filosofante da obra e o uso impreciso do termo humour, palavra mágica que, assim como ironia, já então se tornava um clichê para "explicar" a obra. Até mesmo as observações sobre a pusilanimidade das personagens e o caráter repetitivo e enfadonho da prosa de $\mathrm{M}$ achado não podem ser creditadas a alguém completamente fora do siso. D escontada a antipatia que anima as observações, ao insistir no que havia de anacrônico, imitativo, deslocado e artificioso na prosa machadiana, Romero colocava ou mantinha em pauta questões até hoje presentes e relevantes para o estudo das fontes e influências do romance machadiano.

M as se era capaz de diagnósticos corretos, tinha uma capacidade infinita de confundir os corpos, aplicando suas conclusões, quase que sistematicamente, ao paciente errado. N inguém sofreu tanto com esse talento dissociado e peculiar de Sílvio Romero quanto M achado de Assis.

\section{Araripe J r.: 0 escritor excêntrico}

A reação de Araripe J r. à obra de $M$ achado talvez seja a que ilustra com mais consistência o descompasso entre a produção ficcional de $M$ achado e os gostos arraigados e as expectativas da crítica praticada contemporaneamente ao aparecimento da obra. O sobrinho de J osé de Alencar, que em sua longa atividade deixou a crítica de fundo romântico pelos preceitos da crítica naturalista, descreveu o percurso usual da crítica brasileira no século XIX. Homem afeito a teorias e doutrinas, assim como Romero, seu antigo companheiro da escola do Recife, Araripe também julgará a obra de $M$ achado principalmente pela negatividade, pelo que há nela de incongruente com os preceitos romântico-naturalistas de que a obra literária deve representar e ser representativa do país.

Araripe acompanhou a produção de M achado desde o início da década de 1870, quando publicou um artigo sobre FalenaseC ontosFluminenses ${ }^{10}$, até depois da morte do escritor, sobre o qual escreveu um artigo-necrológio em 1ำ de outubro de 1908. Ao contrário de Sílvio Romero, cuja opinião sobre a obra de $M$ achado, apesar das contradições e incongruências, permaneceu sempre negativa, Araripe J r. reformulou seus juízos ao longo dos mais de trinta anos de crítica machadiana, em vários momentos expondo ou procurando explicitar as limitações ou injustiças cometidas anteriormente. Assim, no texto publicado a propósito do lançamento de QuincasBorba, no início de 1892, Araripe lembra a visão restrita e restritiva de literatura que expressara no início da década de 1870, quando atribuiu a M achado ingratidão para com o "formoso Brasill", acusando o escritor 
pela "manifesta preferência que vota ao grito da cigarra de Anacreonte sobre o melo-dioso canto do sabiá" ${ }^{11}$. Com distância de mais de duas décadas, A raripe justifica as primeiras impressões, muito negativas, diante dos poemas e dos primeiros contos de $\mathrm{M}$ achado, evocando a saturação de romantismo:

N essa época eu andava muito preocupado com a idéia do romance nacional; sabia de cor o Brasil de Ferdinand Denis e lera pela oitava ou nona vez o Guarani de J. de Alencar. No que respeita à literatura, igno rava completamente a existência de uma cousa chamada proporções, pouco tinha observado, muito menos comparado, de modo que, segundo então pensava, não havia senão uma craveira: - diante d'uma obra d'arte, ou tudo ou nada ${ }^{12}$.

A confiar que, em plenos anos de 1870, as expectativas de um crítico bem informado como Araripe $\mathrm{J}$ r. pudessem ser mais ou menos generalizadas entre os homens de letras, os parâmetros da boa ficção ainda eram buscados nos tratados clássicos de Marmontel e Boileau, para quem a narração deve ser viva e movimentada, e os modelos estavam em escritores hoje tão obscuros quanto J oseph $M$ éry, francês, autor de histórias de amor passadas em cenários exóticos. Exotismo muito preferível à "excentricidade" das narrativas de Machado - esse um dos termos recorrentes na crítica de A raripe a M achado - , que punha o seu "chateaubrianismo intransigente em verdadeiro desespero" , indicando que a obra de Chateaubriand, sobretudo aquelas de exaltação da natureza e do índio americano, como R enée A tala, amplamente divulgadas e lidas entre os românticos, eram os modelos que estavam no horizonte de expectativas de boa parte de leitores e críticos locais até bem avançado o século XIX.

Se nos dois artigos que escreveu em 1892 sobre QuincasBorba Araripe J r. desculpa-se pela estreiteza do metro utilizado no início da década de 1870 para julgar a poesia e os contos, o crítico cearense cometia novo deslize ao fazer a célebre restrição às figuras femininas de $M$ achado, que considerava incolores, e às suas heroínas, para ele incapazes de exalar o odor defemina. A opinião sobre a sensaboria e o recato de $\mathrm{M}$ achado em relação às figuras femininas ganhava ares de inconfidência com a explicação que lhe acompanhava: " para bem retratar mulheres, é indispensável senti-las ao pé de si e cheirar-lhes o pescoço, ou brigar com elas, intervindo e perturbando os seus negócios", sentenciava o crítico, para quem "M achado de Assis, asceta dos livros e retraído ao gabinete, não as invadiu por nenhum destes aspectos". As observações, que po dem ser lidas como insinuação de que M achado teria pouca experiência com mulheres, lançando dúvidas sobre sua virilidade ou mesmo sobre os encantos de sua discreta esposa, D. Carolina, de fato magoaram o escritor. V inte e seis anos mais tarde, em 1908, Araripe faria um mea culpa da grosseria cometida contra o autor a propósito do seu julgamento de Sofia Pal ha, relatando as conversas que tivera com M achado depois da publicação do artigo em que, ao tentar reparar um antigo erro, produzira uma nova ofensa.

A ofensa, no entanto, diz muito sobre o instrumental crítico adotado por A raripe, que protesta contra o espanto e o recuo de Sofia Palha diante do assédio 
de Rubião. A comparação inevitável é com o naturalismo. O nde Zola "forçosamente colocaria uma cena de canibalismo amoroso", M achado preservava as aparências, rompendo com a expectativa das descrições mais cruas e carnais das mulheres e do sexo, "das atrocidades irregulares dos tempos modernos", que eram de regra na crítica e no romance naturalista. Com seu recato e contenção, $\mathrm{M}$ achado, segundo Araripe, fazia clamorosa exceção à regra dos brasileiros, afeitos às conversas pornográficas, "sublinhadas pelo vermelhão da lubricidade, clima, ociosidade ou educação" 13 .

$\mathrm{H}$ averia então um duplo deslocamento e excentricidade: do romance em relação aos tempos modernos e do escritor em relação ao meio. Pois M achado será considerado como "um dos raros exemplos de poeta e romancista que, resistindo ao meio e vencendo as hostilidades do próprio temperamento, fiel à vocação, conseguiu completar a sua carreira" ${ }^{14}$. O u seja, a obra machadiana deveria sua especificidade e singularidade principalmente à resistência do escritor ao meio. A referência ao talento e à vocação indica a necessidade de abertura a outros parâmetros, individuais, quase psicológicos, para justificar a exceção, o deslocamento e a excentricidade da obra machadiana; mas também reafirma a prevalência e a centralidade do meio, a cujas influências e determinações a maioria dos escritores sucumbiria, de acordo com o pensamento determinista do tempo. M achado, assim, era a exceção que confirmava a regra. 0 humorismo, apontado por Veríssimo como traço distintivo da obra, e entendido por Romero como afetação do escritor, será compreendido por A raripe como um forma peculiar de humor - o paradoxo literário - , resultante do contato entre um produto exclusivo da raça anglo-saxônia e as novas condições mesológicas e étnicas do Brasil.

Eis aí a aplicação, para fins machadianos, de uma das formulações mais originais do pensamento de Araripe J r., que tinha no meio físico uma de suas categorias centrais. Para argumentar em favor da existência de uma literatura brasileira em período anterior à independência do Brasil, Araripe formulou, em 1887, a curiosíssima teoria da obnubilação brasílica. Segundo essa teoria, a mera travessia do Atlântico e o contato com o meio físico brasileiro seriam suficientes para produzir alterações na sensibilidade e no modo de expressão do colonizador, garantindo a originalidade da produção literária realizada em terras brasileiras. Processo parecido se dava com o humorismo de Swift, Sterne, L amb e Thackeray, ao ser praticado em terras brasileiras, pela imaginação de M achado de Assis.

$M$ as a história da crítica de A raripe J r. à o bra de $M$ achado não é feita apenas de erratas, reparações, tentativas de emendar juízos que o próprio crítico, passados os anos, considera limitados ou infelizes. $\mathrm{H}$ á aqui e ali percepções interessantes e fecundas, que fariam longa carreira na fortuna crítica de M achado. E m "I déias e sandices do ignaro Rubião", de 1893, Araripe chama a atenção para o potencial satírico do romance, composto em torno de uma filosofia excêntrica, o H umanitismo, percebido pelo crítico como conjunção brasileira de princípios do positivismo de Augusto Comte com o evolucionismo de Charles Darwin. A 
misturada, feita no cadinho da loucura de Q uincas Borba e do seu herdeiro, o ignaro Rubião, seria uma alegoria do modo como as idéias estrangeiras circulam e são assimiladas no B rasil, processo caracterizado pelo crítico como "uma espécie de endosmose intelectual" 15 .

Araripe, assim como Romero, também não parece aprovar a irreverência de M achado com dois dos grandes filósofos do século e com coisas tão sérias como as afecções mentais. M as reconhece a carga satírica do romance, sugere que o escritor se diverte por meio de Rubião e pergunta: "Q uem nos diz que este personagem não seja o Brasil?" A interrogação de Araripe reverberaria por toda a vertente crítica que estuda a obra de M achado como condensação dos processos culturais e políticos do Brasil do Segundo Reinado, e para além dele. Ao longo do século $X X$ a mesma pergunta seria recolocada para outros personagens e termos: Q uem nos diz que Brás Cubas, D om Casmurro, Capitu e a obra de $M$ achado de maneira geral não seja o Brasil ${ }^{16}$

$\mathrm{N}$ esse sentido, Araripe vai mais longe que R omero e Veríssimo na percepção sobre o potencial crítico e a natureza nada absenteísta do romance de $\mathrm{M}$ achado de Assis. Enquanto Romero reclama da inconsistência das personagens e da recusa do escritor de se filiar a esta ou aquela corrente do pensamento, Araripe percebe 0 ardil ficcional e intui a extensão da descrença machadiana de que haja algo assaz fixo neste mundo. Enquanto Veríssimo identifica em Quincas Borba um progresso de $\mathrm{M}$ achado em relação ao parâmetro da literatura nacional, no sentido de que ali estariam colocados tipos e situações "eminentemente nossas" , A raripe surpreende na filosofia de Quincas Borba um procedimento característico do pensamento nacional, no modo como o brasileiro Rubião, um ignorante, se relaciona com as idéias de Comte e D arwin.

\section{Veríssimo: o escritor à parte}

D iferentemente de R omero e Araripe J r. que, comprometidos com doutrinas científicas, procuravam compreender a obra de M achado por critérios principalmente evolucionistas, no caso do primeiro, e romântico-naturalistas, no caso do segundo, Veríssimo a certa al tura parece perceber a insuficiência dos parâmetros disponíveis diante da singularidade e da grandeza da obra de M achado de Assis. Q uando escreve, no seu artigo sobre QuincasBorba, que a obra de M achado de Assis não pode ser julgada segundo o critério que chama de "nacionalístico", questionando o parâmetro adotado por Romero na sua H istória da literatura brasileira, Veríssimo anuncia a tomada de rumo diverso e dá um passo importante para a desvinculação entre o valor da obra e o empenho do escritor em retratar a cor local e construir uma literatura nacional.

0 relaxamento dos critérios etnográficos e geográficos, recorrentes e comuns à crítica romântica e naturalista, tirava o foco da paisagem local, cuja ausência na obra machadiana seria um dos lugares-comuns da crítica machadiana. N otada por Romero, a lacuna receberá interpretação favorável de Veríssimo: 
N o mundo só Ihe interessa de fato o homem com os seus sentimentos, as suas paixões, os seus móveis de ação [...] sem Ihe dar da decoração, da paisagem, dos costumes, do que apenas se servirá para criar aos seus personagens e aos seus feitos o ambiente indispensável, porque sendo entes vivos não podem viver sem ele $\mathrm{e}^{17}$.

O critério nacionalista, diga-se de passagem, não era só de Romero, mas parâmetro dominante entre a crítica praticada no Brasil até a década de 1880, incluído-se aí a produção do próprio crítico paraense, que só ao longo dos anos de 1890 se distanciou dos model os positivistas e natural istas, deslocando a ênfase para aspectos psicológicos e estéticos. Ainda assim, os critérios nacionalistas estão ativos quando Veríssimo considera Quincas Borba um romance completo, por ser romance de caráter e de costumes, e um progresso da literatura nacional, por trazer uma porção de tipos e situações eminentemente nossas.

A resenha sobre QuincasBorba, que marca o início da contribuição de Veríssimo para a crítica machadiana, é também o anúncio da renovação do seu programa crítico. Ali, Veríssimo declara seu horror a todas as seitas, sejam elas políticas, literárias ou religiosas, e proclama: “O Sr. M achado de Assis não é nem um romântico, nem um naturalista, nem um nacionalista, nem um realista, nem entra em qualquer dessas classificações em i smo ou ista. É, aliás, um humorista" ${ }^{18}$. Ao colocar M achado de Assis como um escritor à parte, especial, e associar sua singularidade à categoria filosófico-literária do humorismo, Veríssimo retirava o escritor do enquadramento localista, alçando-o à condição de escritor universal, sem que isso representasse rebaixamento, demérito, anacronismo ou excentricidade. Com isso, Veríssimo inaugurava outra vertente para a crítica machadiana, que busca na obra de M achado pulsações filosóficas e existenciais, válidas não só no Brasil, mas em todos os quadrantes.

A partir daí, as discussões em torno do humor e do humorismo estariam diretamente associadas à tensão entre o nacional e o universal na obra de $\mathrm{M}$ achado de Assis, outro dos cabos de força da crítica machadiana, que encontraria algum equilíbrio feliz na obra de Lúcia M iguel-Pereira, já avançado o século XX. De que modo o humour filiava $M$ achado a tradições estrangeiras, e a quais tradições esse será assunto obrigatório e motivo de disputa entre os contemporâneos, com desdobramentos na crítica póstuma. 0 primeiro estudo de fôlego sobre $\mathrm{M}$ achado de Assis, publicado depois de sua morte, foi M achado deA ssis- algumasnotassobre o humour, de Alcides M aya. N esse livro de 1912, M aya procura aplainar o terreno revolvido, depois de Veríssimo, também por Araripe Júnior, M agalhães de Azeredo, Walfrido Ribeiro, O liveira Lima, Alcindo Guanabara e M ário de Alencar.

A indicação do humor como parâmetro crítico, vale notar, fora soprada pelo próprio M achado, naquele prólogo "Ao leitor" que abre a versão em livro das M emóriasPóstumase associa a prosa de Brás C ubas à maneira livre de Sterne. A referência inglesa fora indicada por um certo Abdiel (pseudônimo de Artur Barreiros) em crítica sobre BrásC ubas, mas foi Veríssimo quem colocou o humor 
como elemento central da obra machadiana. E ssa foi uma das percepções fecundas de Veríssimo, entre os críticos da tríade machadiana certamente o que teve mais proximidade e afinidade com o escritor, com quem conviveu e manteve correspondência. Veríssimo também será o primeiro a chamar a atenção para a natureza pouco confiável do narrador de Dom Casmurro, ao mesmo tempo envolvido e distanciado dos fatosque narra, condição que poderia torná-lo suspeito aos olhos do leitor. M as sua grande percepção crítica talvez esteja no estabelecimento de relação entre a linguagem adotada nos romances em primeira pessoa, o tempo da ação, o meio retratado e o perfil dos narradores-personagens. I sso se dá na resenha sobre D om Casmurro, onde postula o parentesco entre Brás Cubas e Bento Santiago para buscar a especificidade de feição e índole entre os dois narradores-personagens.

A té então, isso já era em 1900, a crítica reiteradamente expressara frustração com a falta de imaginação, a pouca movimentação e a frieza dos enredos de $\mathrm{M}$ achado de Assis, compensadas pela excelência do estilo, original, correto e respeitoso à língua castiça. Ao associar D om Casmurro e Brás C ubas para contrastá-los, o crítico sugere o parentesco filosófico entre os dois personagens, semelhantes no modo de considerarem as coisas, mas diferentes no modo de expressá-las, por serem personagens de momentos históricos distintos, cujas diferenças de alguma forma poderiam ser percebidas na pró pria linguagem que adotam, construída pelo talento de M achado de Assis e atribuída pelo escritor aos protagonistas:

Se Brás Cubas e D om Casmurro contam ambos os dous a sua história, cada um tem o seu estilo, a sua língua, a sua maneira de contar. No que mais se assemelham é no fundo da sua filosofia e no modo de considerar as cousas. $M$ as ainda assim há no homem do primeiro reinado e da regência, que era Brás C ubas, e no homem do segundo império, que foi D om C asmurro, sensíveis diferenças de épocas, de civilização, de costumes ${ }^{19}$.

Veríssimo percebe nuances no estilo de Machado, até então considerado como único e singular, até por ele mesmo, que al guns anos antes colocara tudo sob o nome de humorismo. Ao notar que a narração em $D$ om Casmurro se dá em vários planos, de modo que Dom Casmurro, Bento Santiago e Bentinho não são exatamente um mesmo, intui que o escritor M achado de Assis e os narradores de seus romances também não são entidades coincidentes. Veríssimo entende que há alguma outra coisa que se so brepõe a esse estilo - o esforço de verossimilhança que o escritor procura atribuir aospersonagenscomo homens "do seu tempo eda suaclasse" :

Basta comparar-Ihes a linguagem. C erto o estilo é o mesmo. Pois é o estilo de um escritor feito, e se não muda de estilo como de pena. Só o trocam os que de fato não o têm, e menos poderia reformá-lo um escritor completo, como 0 Sr. M achado de Assis, e que o possui com uma individualidade como nenhum outro dos nossos. M as se não é possível mudar de estilo sem mudar de personalidade, não é impossível variá-lo, consoante as condições, os gêneros, os personagens, a índole, a natureza da ação ou da composição da obra literária ${ }^{20}$. 


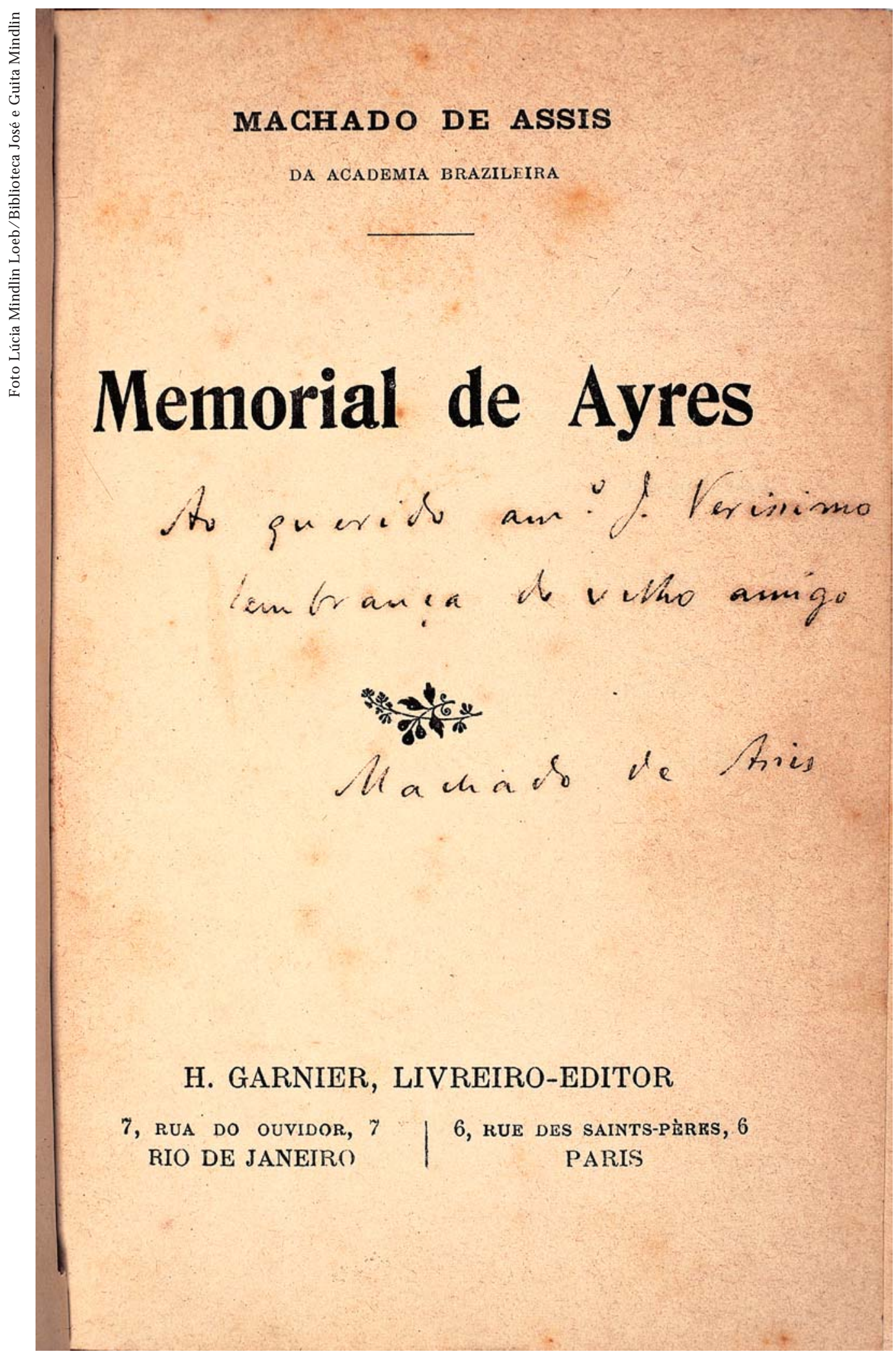

Fol ha de rosto de M emorial de Aires. R io de Janeiro, Garnier,1908. 
O u seja, as marcas do tempo e do espaço não estão no assunto, no tema, no espírito ou no estilo do escritor, mas na linguagem das personagens, forjada pelo talento do escritor. Assim, o conteúdo pouco variado, o entrecho pouco movimentado e a monotonia da narração, tão freqüentemente observad os pelos contemporâneos, talvez não fossem defeitos nem indícios de falta de habilidade, mas aspectos significativos e importantes para o bom rendimento ficcional dessas narrativas, além de responderem ao que Veríssimo chamou de "critério de beleza" 21 do escritor.

Ao chamar a atenção para o talento individual e para a dimensão estética da o bra literária, Veríssimo arejava a atmosfera crítica dos determinismos ambientais e sociais que marcaram a crítica de sua geração. Claro que isso tinha um preço, que era o risco de cair na crítica impressionista. No caso específico do romance de $\mathrm{M}$ achado, o distanciamento dos métodos críticos então consagrados de fato resultou em impressionismo e contradição, mas também permitiu uma aproximação do texto machadiano maior que Romero e Araripe jamais tiveram. A leitura mais rente permitiu a Veríssimo captar questões técnicas da construção do romance machadiano - como a dos vários planos narrativos de D om Casmurro, por exemplo; ou da exacerbação do humorismo nos romances da segunda maneira do escritor - que as malhas grossas do arsenal crítico da época não foram capazes de apreender.

$\mathrm{N}$ os cinco textos dedicados aos romances de $\mathrm{M}$ achado - entre os contemporâneos, ele foi o único a comentar todos os romances de M achado a partir de Q uincasBorba, escrevendo ainda so bre a segunda edição de l aiá Garcia, lançada em 1898 - Veríssimo expressa também seu desnorteamento diante da obscuridade de algumas formulações, o desagrado com o rebuscamento excessivo e um certo desconforto ante ao "atilado pessimismo" de M achado de Assis. Ao comentar D om C asmurro, Veríssimo entrega os pontos diante da concepção desencantada e da desilusão completa dos móveis humanos que emanam dos romances de $M$ achado de Assis. E formula este curioso desejo: que M achado desenvolvesse um modo mais piedoso e mais humano de conceber a vida.

A pesar do esforço de compreensão e da empatia com o autor e com a obra, Veríssimo também estranhou a dicção e a postura, deixando evidente o desafio que a literatura de M achado de Assis colocava, e ainda hoje coloca, para seus leitores. Porém, talvez porque mais desembaraçado de doutrinas absolutas, Veríssimo pôde ouvir melhor que seus contemporâneos as questões complexas suscitadas pelo romance machadiano. E não eram poucas, já que M achado, ao abandonar a atividade crítica, que exerceu com argúcia excepcional até o final da década de 1870, deslocava seu pendor crítico para dentro do ambiente e da fatura de sua ficção. É de lá, por meio de Brás Cubas, Rubião, Dom Casmurro e o C onselheiro Aires que o escritor passava a exigir novos parâmetro críticos - e também a zombar um pouco - dos contemporâneos e dos pósteros. 
N otas

1 Sobre o enquadramento de cada um dos críticos, ver Antonio $C$ andido, 0 método crítico deSílvio R omero, 3a ed., São Paulo, Edusp, 1988; Alfredo Bosi (org. ), A raripe Júnior - Teoria, crítica ehistória literária, Rio de Janeiro/ São Paulo; LTC/ Edusp, 1978; J oão Alexandre Barbosa, J oséVeríssi mo - Teoria, crítica ehi stória literária, R io de Janeiro/ São Paulo; LTC/Edusp, 1978. Sobre as polêmicas entre Romero, Veríssimo e Araripe J r. e as divergências entre eles, ver Roberto Ventura, Estilo tropical - história cultural epolêmi casliteráriasno Brasil, São Paulo, Companhia das L etras, 1991.

2 J osé Anastácio, "Q uincas Borba”, 0 Tempo, Rio de Janeiro, 25/ 1/ 1892, p. 1. Esta e outras resenhas publicadas na imprensa entre 1872 e 1908 a propósito dos lançamentos dos romances de $M$ achado de Assis estão reunidas em Os leitores de $M$ achado de A ssis - romance machadiano e poølico de literatura no século XIX, de H élio de Seixas Guimarães, São Paulo, Edusp/ N ankin, no prelo.

3 Carlos M agalhães de Azeredo, "Q uincas Borba", O Estado de S. Paulo, São Paulo, $19,20,21,24,26$ e 27/ 4/ 1892.

4 J osé Veríssimo, "Às segundas-feiras - um novo livro do Sr. M achado de Assis", J ornal do Brasil, Rio de Janeiro, 11/ 1/ 1892, pp. 1-2.

5 Araripe J r., "B rás Cubas", Lucrose Perdas, Rio de Janeiro, 1885.

6 Sílvio Romero, "O naturalismo em literatura”, Literatura, história e crítica, L uiz Antonio Barreto (org.), Rio de Janeiro/ Aracaju; I mago/ U niversidade Federal de Sergipe, 2002, pp. 341-367.

7 Sílvio Romero, Machado de A ssis- Estudo comparativo de Literatura Brasileira, Rio de Janeiro, Laemmert \& C., 1897, p. XIX.

8 I dem, p. 6.

9 I dem, p. 164.

10 Araripe J r., sob pseudônimo de 0 scar J agoanharo, Dezesseis dejulho, Rio de J aneiro, 6/ 2/ 1870.

11 I dem, ibidem.

12 Araripe J r., Gazeta de N otícias, Rio de Janeiro, 12/ 1/ 1892, p. 1

13 I dem, ibidem.

14 Araripe Jr., "M achado de Assis", R evista Brasileira, Rio de J aneiro, jan.-mar. 1895, pp. 22-28. Reproduzido em Obra crítica deA raripe únior, vol III, Rio de Janeiro, M inistério da Educação e C ultura, Casa de Rui Barbosa, 1963, pp. 5-9.

15 Araripe J r., "I déias e sandices do ignaro Rubião". Gazeta deN otícias, Rio de Janeiro, 5/ 2/ 1893, p. 1.

16 Sobre a pergunta de Araripe e o conflito entre interpretações localistas e universalistas, ver Roberto Schwarz, "D uas notas sobre M achado de Assis", em Que horas são?, São Paulo, Companhia das Letras, 1987. 
17 J osé Veríssimo, "Revista litteraria - N ovo livro do Sr. M achado de Assis" , J ornal do Commercio, Rio de Janeiro, 19/ 3/ 1900, p. 1.

18 J osé Veríssimo, "U m novo livro do Sr. M achado de Assis", J ornal do Brasil, Rio de Janeiro, 11/ 1/ 1892, pp. 1-2.

19 J ornal do Commercio, Rio de Janeiro, 19/3/ 1900, p. 1

20 I dem.

21 J osé Veríssimo, "Esaú e J acó o último livro do Sr. M achado de A ssis", Rio de J aneiro, K osmos, 1904, pp. 28-29.

R ESU M O - O ARTIGO trata dos desafios e mudanças de parâmetro que a literatura machadiana colocou para a crítica oitocentista, desestabilizando as concepções até então vigentes do literário e colocando em xeque a aplicação rígida das teorias e doutrinas então disponíveis. 0 texto mostra que crítica machadiana toma corpo à época da publicação de QuincasBorba, com a formação da tríade Romero-Araripe-Veríssimo, que se concentra em questões como a do humorismo e da representatividade nacional do romance, com desdobramentos importantes nos estudos futuros sobre a obra de M achado de Assis.

A BSTRACT - THIS ESSAY deals with the challenges and changes in parameters that M achado de Assis' literature placed upon $19^{\text {th }}$ century critics, destabilizing the literary concepts in effect at the time and questioning the strict application of prevailing theories and doctrines. The essay shows that criticism of Assis really takes hold upon the publication of Quincas Borba, when the triad Romero-Araripe-Veríssimo arose, and focused on issues such as the novel's humor and its representativeness of the national mood, which had an important influence on future studies of the work of M achado de Assis.

H élio de Seixas Gui marães é professor de Literatura Brasileira na U niversidade de São Paulo, autor de Os leitores de Machado de Assis - romance machadiano e público de literatura no século XIX (Edusp/ N ankin, no prelo).

Texto recebido e aceito para publicação em 2 de julho de 2004. 


\section{A lgunstextos do calor da hora ${ }^{1}$}

\section{Sílvio Romero sobre BrásC ubas e o humorismo de M achado de Assis}

“A passagem de Emílio Zola para o sr. M achado de Assis é um destes saltos mortais da inteligência provocados pela lei dos contrastes. D epois de um talento, de um estilista, de um crítico sincero, de um romancista de força, de um homem, avistar um meticuloso, um lamuriento, um burilador de frases banais, um homenzinho sem crenças... é uma irrisão! M as é preciso romper o enfado que me causa essa tênia literária e despi-la à luz meridiana da crítica. Esse pequeno representante do pensamento retórico e velho no Brasil é hoje o mais pernicioso enganador, que vai pervertendo a mocidade. Essa sereia matreira deve ser abandonada. 0 autor de l aiá Garcia, frívolo e inofensivo como é, é tanto mais para ser combatido, quanto pela dubiedade de seu caráter político e literário em nada pode ajudar a geração que se levanta e a que insinua-se por amigo. N ão tendo, por circunstâncias da juventude, uma educação científica indispensável a quem quer ocupar-se hoje com certas questões, e aparecendo no mundo literário há cerca de vinte e cinco anos, o sr. M achado de Assisé um desses tipos de transição, criaturas infelizes, pouco ajudadas pela natureza, entes problemáticos, que não representam, que não podem representar um papel mais ou menos saliente no desenvolvimento intelectual de um povo. Q uando ele apareceu já na E uropa o romantismo entrava plenamente em dissolução e no Brasil o olhar exercitado podia bem distinguir os germens de decadência que lhe rompiam no seio. 0 romantismo já tinha produzido entre nós suas melhores obras na poesia, no romance e no drama. M agalhães, Porto Alegre, Pena, G. D ias, Álvares de Azevedo, $M$ acedo, Teixeira e Souza, Junqueira Freire para só falar nestes oito, haviam levado a efeito suas melhores produções e criado em torno de si uma multidão de epígonos. Alencar já tinha produzido seu Guarani, rasgando novos horizontes ao romance nacional. 0 sr. M achado tinha, portanto, de ocupar um lugar secundário na cauda do romantismo, na frase de Zola, a não ser ele uma inteligência superior. É o que não é, e por isso ficou justamente no lugar que lhe competia.

N atureza eclética e tímida, sem o auxílio de uma preparação conveniente, entrou a ser um parasita, espécie de comensal zoológico, vivendo à custa de uma combinação do classicismo e do romantismo. N ão teve força bastante para romper com ambos, e foi sempre vacilante em seus cometimentos. Os autores que deixei acima lembrados, quaisquer que sejam os seus defeitos, na evolução intelectual

1 Os textos de Araripe Jr. e J osé Veríssimo, publicados em jornais, foram extraídos de Os lei tores de M achado de A ssis - romance machadiano e público de literatura no século XIX, de H élio de Seixas Guimarães, a ser lançado pela Edusp/ N ankin. O livro reúne em seu apêndice o conjunto dos textos publicados na imprensa sobre os nove romances de $M$ achado de Assis à época de suas edições em livro. A grafia dos textos segue rigo rosamente a grafia original, incluindo deslizes tipográficos e erros. 
brasileira neste século, representam os elos de uma cadeia. Cada um deles tem um sentido e uma fisionomia própria. E o sr. M achado o que representa? É um digno camarada de E. Taunay, e Luís D elfino, sendo talvez ainda menos significativo do que eles. 0 sr. M achado simboliza hoje o nosso romantismo velho, caquético, opilado, sem idéias, sem vistas... lantejoulado de pequeninas frases, ensebadas fitas para efeito. Ele não tem um romance, não tem um volume de poesias que fizesse'época, que assinalasse uma tendência. É um tipo morto antes de tempo na orientação nacional.

As condições de sua educação, o meio falso em que há vivido explicam o seu acanhamento. Pôde iludir e ilude ainda a alguns ignorantes pela palavrosidade de seus períodos ocos, vazios, retortilhados e nada mais. Por duas vezes o inconsciente das coisas favoreceu-lhe o momento de tomar uma direção fecunda, se para isso tivesse talento e habilitações; uma foi na luta entre J osé de Alencar e J osé C astilho, outra nos últimos anos diante das novas idéias inauguradas desde 1869 no país.

0 que temos visto, porém? No primeiro momento aquele homem dúbio teve bastante habilidade, bastante jeito para não tomar um partido no debate. M eio clássico e meio romântico, precisando de ambos os lutadores, prendendo-se a um pela monomania do lusismo na língua, e a outro pelos arremedos imaginativos, conservou-se o amigo e o imitador dos dois inimi gos!. . I sto é colocar a mão sobre a ferida intelectual do homem.

Agora vemo-lo sem força para romper com o passado e seguir uma qualquer das novas tendências... Sentindo o terrenos fugir-lhe debaixo dos pés, prega 0 opor tuni smoli terário, faz-se de grão-conselheiro, elogia por cálculo a velhos e moços, e, quanto às idéias, não segue nenhuma; porque não as compreende. A prova é que em seus escritos de todo o gênero, é ainda um velho romântico desconcertado e banal. Vive a sonhar com a M osca A zul... E é um tal homem que se nos quer inculcar como um modelo!

Sem convicções políticas, literárias ou filosóficas, não é, nunca foi um lutador. Esse auxiliar de todos os ministérios, esse rábula de todas as idéias, é, quando muito, o conselheiro da comodidade letrada. 0 que ele quer é representar o seu papel equívoco. $\mathrm{O}$ autor de BrásC ubas, bolorenta pamonha literária, assaz o conhecemos por suas obras, e ele está julgado. Continue a burilar frases inúteis, a produzir suas bombinhas da China, mas tenha o cuidado de conter-se na vacuidade embaumée pelos elogios de seus comparsas inconsiderados."

[Trecho de 0 naturalismo em literatura (1882). Extraído de BAR RETO, L uiz Antonio. Li teratura, história ecrítica - Sílvi oR omero. Rio de Janeiro/ I mago; Aracaju/ U niversidade Federal de Sergipe, 2002, pp. 358-360]

"O celebre fluminense passa, aos olhos de certa critica indigena, como o typo mais completo do humorismo entre nós. Tenho algumas dúvidas a oppôr a esse modo de julgar, que se me antolha soffrivelmente falso.

O tão apregoado cultivo do humour no autor do Yayá Garcia não é natural e espontaneo; é antes um resultado de uma aposta que o escriptor pegou comsigo mesmo; é um capricho, uma affectação, uma cousa feita segundo certas receitas e 
manipulações; é, para tudo dizer n'uma palavra, uma imitação, aliás pouco habil, de vairos autores inglezes.

A prova está em que similhante nota não apparece, incondicional eirreductivel, nos mais antigos trabalhos do famoso romancista.

O ra, o humour não é cousa que se possa imitar com vantagem; porque elle só tem merecimento quando se confunde com a indole mesma do escriptor.

O humour de imitação é a caricatura mais desasada que se póde praticar em litteratura.

O humorista é, porque é e porque não póde deixar de ser. Dickens, Carlyle, Swift, Sterne, $\mathrm{H}$ eine foram humoristas fatalmente, necessariamente; não podia ser por outra fórma. A indole, a psychologia, a raça, o meio tinha de fazel-os como foram. 0 humorismo não é cousa que se possa guardar n'uma algibeira para n'um bello dia tirar para fóra e mostrar ao publico.

Thomas H ood, H eine, D ickens, Fielding, Sterne, Carlyle, Richter, ninguem de bom senso póde acreditar que escrevessem as A meri canas, H elena, Yayá Garcia, A M ão ea Luva, R esurrei ção, C hrysalidas, isto é, seis livros onde tudo póde existir, menos o humour, seis livros que representam um grande mor tali soevi spatium do poeta, sem que este désse, de longe ou de perto, o menor signal de occultar em si o espirito mephistophelico dos humoristas de raça.

$M$ achado de Assis hoje é fundamentalmente o mesmo eclectico de trinta ou quarenta annos atraz: meio classico, meio romantico, meio realista, uma especie de juste-milieu litterario, um homem de meias tintas, de meias palavras, de meias idéas, de meios systemas, aggravado apenas com a mania humorista, que não Ihe vai bem, porque não fica a caracter n'um animo tão calmo, tão sereno, tão sensato, tão equilibrado, como é o autor de Tu sò, tu, puro amor.

$\mathrm{H}$ ontem, como hoje, a manifestação mais aproveitavel de seu talento foi certa aptidão de observação comedida e a capacidade de a revestir, em suas obras, de uma fórma correcta, posto que nem a observação fosse profunda, nem a fórma brilhante.

$\mathrm{H}$ ontem o poeta e romancista diluia por tudo aquillo certo lyrismo, doce, suave, tranquillo; hoje tem velleidades de pensador, de philosopho, e entende que deve polvilhar os seus artefactos de humour, e, ás vezes, de scenas com pretensão ao hor rivel.

Quanto ao humour, - prefiro o de Dickens e de H eine, que era natural e incoercivel; quanto ao horrivel, agrada-me muito mais o de Edgar Poë, que era realmente um ébrio e louco de genio, ou o de Baudelaire, que era de fato um devasso e epileptico. O humour de M achado de Assisé um pacto director de secretaria de Estado, e o horrivel em seus livros é uma especie de burguez prasenteiro, condecorado com a commenda da rosa...

$\mathrm{N}$ em interessam e nem mettem medo.

Podem figurar nas paginas das folhinas e almanaks entre as pilherias contra as sogras.

O temperamento, a psychollogia do notavel brasileiro não são os mais proprios para produzir o humour, essa particularissima feição da indole de certos povos. N ossa raça em geral é incapaz de o produzir espontaneamente. 
$\mathrm{N}$ ão su em quem o diz; são os maiores mestres da critica em nosso tempo. $\mathrm{H}$ ennequin, Taine e Scherer são unanimes dem declaral-o: o primeiro a proposito de D ickens, o segundo em relação a Carlyle, o ultimo falando de Sterne.

E como muita gente, que se diz muito adiantada e singularmente sabida, anda ahi a confundir aquelle especial sainete do espirito gemanico com a ironia, e até com o comico, o chiste, a graça, a pilheria proprios dos povos latinos, não é fóra de proposito lembrar a $M$ achado de Assis que até elle mesmo anda illudido sobre uma qualidade espiritual, que Ihe não assenta como ingenuamente acredita."

[T recho do capítulo XIII de Machado deA sis- etudo comparati vo deli teratura brasi lei ra, Rio de Janeiro, Laemmert \& C. E ditores, 1897, pp. 131-134]

\section{Araripe Júnior sobre Quincas Borba}

"O s primeiros trabalhos de M achado de Assis que folheei foram as Phalenase os Contos Fluminenses

Tinha eu então a meu cargo os folhetins de critica do D ezeseis de Julho, jornal politico que se publicava n'esta capital em 1870.

O s dous livros chegavam de Pariz, nitidamente editados, se não me falha a memoria, pela casa Garnier.

Sendo-me entregues, para os fins convenientes, atirei-me a elles como gato a bofes, certo de que alli encontraria onde afiar o gume do meu cutelo de critico incipiente.

$\mathrm{N}$ 'essa época eu andava muito preoccupado com a idéa do romance nacional; sabia de cór o Brasil de Ferdinand D énis e lêra pela oitava ou nona vez o Guarany de J. de Alencar. No que respeita á litteratura, ignorava completamente a existencia de uma cousa chamada proporções; pouco tinha observado, muito menos comparado, de modo que, segundo então pensava, não havia senão uma craveira : - diante d'uma obra d'arte, ou tudo ou nada.

D'ahi uma consequencia - as Phalenas seriam toleraveis, mas os Contos mereciam morte afrontosa e violenta. E screvi o folhetim indignado e descansei no fim da obra, certo talvez de ter causado a ruina de um edificio colossal.

Como são agradaveis estas illusões e perversidades infantis!

O que é certo é que n'esses venturosos tempos, apadrinhado com as auctoridades, entre outras, de $\mathrm{M}$ armontel, eu julgava facilimo soltar as velas em mar alto. Citava a proposito de estylo o - soyez vif et pressé dans vos narrations - de Boileau; em materia de romance não via nada que excedesse a M ery, nas suas, incontestavelmente deliciosas, phantasias de Florida, H éva, e Guerra do N izan; e como cada qual exige o vinho que apetece, entendia que M achado de Assis devera ter fabricado contos iguaes aos de B occacio e $L$ afontaine ou reproduzido á brasileira as $\mathrm{N}$ oi tes do romancista marselhez. $\mathrm{O}$ futuro auctor das M emorias de Braz Cubas, porém, não trahiria o seu temperamento; e porque já, a este tempo, tinha descoberto o seu caminho, escrevera as historias de Luiz Soares, de M iss D olar e os Segredos de 
A ntônia ${ }^{2}$, cuja excentricidade punham [sic] o meu gôsto artístico, o meu chateaubrianismo intransigente, em verdadeiro desespêro. Êste desespêro foi traduzido na frase iracunda que mais devia ferir o escritor criticado. Em última análise, o pai dos dois livros dera ao público uns contos completamente ocos, vazios de interesse.

E tudo isto se dizia em um jornal dirigido por J. de Alencar, o mesmo J. de Alencar que, poucos mezes antes, do seu ninho da Tijuca escrevera a M achado de Assis uma carta, apresentando-Ihe o poeta Castro Alves e brindando o auctor das Phalenas com o titulo de principe da critica brasileira.

Talvez que isto mesmo fosse a causa principal e inconsciente da minha irritação. O principado devia começar pelas obras de creação e não de eleição.

Este modo de pensar não agradou ao director da folha, e, gerando duplo dissentimento, terminou mais tarde, sob o pretexto que mais decente se me afigurou, pela minha sahida da collaboração de um jornal para o qual entrára como para o paraiso de $\mathrm{M}$ ahomet.

Correram os tempos e variada sorte tivemos depois d'isto.

$M$ achado de Assis continuou sua vida com a pertinacia de que são capazes os $\mathrm{N}$ arcisos litterarios. A paixonado do proprio espirito, procurando em toda parte 0 reflexo de si mesmo, nos livros, nas bibliothecas, nos museus, nas collecções, nos jornaes, nos theatros, nos salões, nas reuniões de amigos, na rua do O uvidor; ruminando a originalidade de suas obras, entre a preoccupação do applauso popular e o horror á vulgaridade; flagellado continuamente pela obsessão do novo e pela imposição dos classicos, M achado de Assis fortaleceu-se na idéa e aprimorou-se na fórma; mas hoje, como hontem, como em 1870, posso affirmal-0, não mudou uma linha do seu primitivo eixo. Subiu, subiu muito alto; porém a linha ou as linhas que prendem o seu papagaio multicor, são as mesmas com que elle o empinava quando menino, isto é, na época em que surgiam os seus primeiros livros.

Vem de molde, pois, dizer de que natureza são estas linhas, e se por alguma d'ellas pôde 0 auctor fazer descer a scentelha de Franklin.

Duas; duas são as tendencias que encontro no espírito litterario de M achado de Assis: uma symbolizada nas Phalenas, outra nos Contos Fluminenses, o que, em termos habeis, quer dizer que o escriptor de 1870, até esta data, não tem feito outra cousa senão desenvolver ou aggravar os dous traços com que desde logo estygmatizou a sua esthetica.

Phalenas significam na sua biographia o mesmo que amor á correcção, ao modulo heleníco, ao compasso; cuidado, e vaidade na roupagem poetica; gosto pela erudição; paixão litteraria!

Dellas brotaram naturalmente as obras em que M achado de Assis mais se approxima da mulher - Yayá Garcia, H elena, R esurreição, e todas as paginas dos seus livros em que se falla de relações sexuaes, do eterno feminino, e da vida fluminense. $\mathrm{N}$ ão ha nessa linha nem observação, nem psychologia, embora o auctor

2 Esse título, ilegível no exemplar do jornal consultado, aparece dessa forma na edição da Obra Crítica de A raripe únior, mas deve referir-se ao conto 0 segredo de A ugusta. 
se proponha estudar caracteres e fazer retratos d'aprèsnature. A percepção dos factos é sempre tenue e superficial, a analyse das cau sas determinantes amarrada ao a pri ori . Tudo se resolve numa collecta de traços geraes; tudo se transforma em um diletantismo mystico, dentro do qual o espirito do poeta gira sem maldades, sempre distrahydo do travo real das cousas, envolvendo os seus personagens, as suas paizagens em um nevoeiro dourado de sol poente.

Composições assim dispostas agradam ás moças e poem n'alma de quem as lê, umas notas suaves, se bem que ponteadas de vez em quando pelas invasões de um outro $M$ achado de Assis, que se esforça por não perturbar a harmonia do livro actual.

Isto não quer dizer que o psychologo allemão não busque ser penetrante e mesmo inexoravel. Nos trabalhos a que alludo encontra-se, ao envez disso, um constante esforço para convencer-nos de que os caracteres por elle exhibidos são complicados e extraordinarios. 0 estylo aponta-se em reticencias venenosas; as phrases empinam-se, de vez em quando annunciando que vai apparecer algum monstro como Yago ou G locester ; mas chega-se ao fim do capitulo ou do livro e com surpreza reconhece-se que a complicação não passava de susto do auctor a quem o pequeno desvio da burgueza já se affigurava o prodromo de inauditas atrocidades.

$\mathrm{N}$ ão pôde exprimir as atrocidades irregulares dos tempos modernos 0 temperamento que, espontaneo, se affeiçoou ao modulo dos gregos; e se esse temperamento não tem força para a contemplação objectiva, acaba por arrojar-se para dentro de si mesmo, transformando os seustics, as suas pequenas excentricidades, os accidentes de sua imaginação enclausurada na expectação interior, nos curiosos typos do romance.

$M$ achado de Assis tem andado entre $O$ ctave Feuillet e L aurence Sterne; duas naturezas apparentemente diversas, uma de angora, outra de urso philosopho. Eu prefiro a ultima e por isso gosto mais de Braz Cubase de QuincasBorba, do que da Yayá Garcia e da H elena.

Asmulheres do auctor de Q uincasBorba são em regra incolores, sem expressão.

O motivo d'esta fraqueza acha-se na estructura do talento de quem as imaginou. Os grandes pintores do genero foram sempre emeritos conquistadores, como Shakespeare, Boccacio, Byron e D umas, pai, ou insignes mexeriqueiros, como Brantôme, Saint Simon e Balzac. Para bem retratar mulheres, é indispensavel sentil-as ao pé de si e cheirar-Ihes o pescoço, ou brigar com ellas, intervindo e perturbando os seus negocios.

M achado de Assis, asceta dos livros e retrahido ao gabinete, não as invadiu por nenhum d'estes aspectos; e por isso as suas heroinas não despedem de si esse odôr de femina, que se aspira ainda nos typos mais angelicos de Shakespeare, como por exemplo, D esdemona.

O utro tanto não succede relativamente aos typos masculinos. E' certo que estes distanciam-se muito da vérdade, encarados como reflexo do mundo objectivo; mas, attendendo a que o auctor tira os elementos com que os constróe, em grande 
parte, da observação de si mesmo, esses typos ganham em excentricidade o que perdem em exactidão, e por tal motivo tornam-se de um interesse pal pitante para 0 leitor desprevenido, apenas preoccupado com o desejo de entreter-se, através do livro, com o espirito do escriptor.

Sob este ponto de vista, folgo de poder hoje repetir o que em 1883 dizia a respeito das $\mathrm{M}$ emoriasposthumasdeBraz $\mathrm{C}$ ubas: " $\mathrm{O}$ livro mais exquisito de quantos se têm publicado em lingua portugueza. »

D e facto, o Quincas Borba confirma, em plena floração, as qualidades excentricas, que, n'aquella primeira parte da da [sic] obra, se affirmavam de um módo categorico.

$\mathrm{N}$ 'esses dois livros, $\mathrm{M}$ achado de Assis entrega-se francamente a to da fuga do seu genio paradoxal ; e se alguma vez decai, deve-o a ter por descuido deixado abrir a porta por onde entram de vez em quando uns idyllios, quero dizer, umas paginas perdidas dos romances amorosos anteriores.

Dir-se-hia que o humorista tem receio de ficar completamente a sós com o seu humor, e por cautela, á maneira de certos dilettantes que se entregam ao autohypnotismo, deixa a entrada do gabinete entre-aberta, afim de que possa receber soccorros das pessoas de fora, quando porventura os macaquinhos azues, de envolta com os bons espiritos invocados, venham perturbar-lhe a imaginação e a tranquillidade d'aquella gymmastica [sic] litteraria.

E quem sabe se n'estas phrases não estou eu traduzindo a exacta situação do animo do escriptor?

E' preciso conhecer $M$ achado pela sua feição mais curiosa: a do causeur.

$\mathrm{N}$ ós brasileiros, de ordinario, preferimos cultivar a conversa de estylo pornographico. Noventa por cento das phrases diariamente emittidas na rua do O uvidor, ou são claramente bocagianas, ou sublinhadas pelo vermelhão da lubricidade, clima, ociosidade, ou educação; qualquer explicação póde ser acceita; mas o que está verificado, é que nós raramente estamos dispostos para fazer diante de um copo de cerveja allemã um duetto sobre philosophia, ou uma ola podrida litteraria.

Se o sensualismo não nos invade, cahimos na politica pessoal e nas conspirações que todos escutam, todos sabem, todo o mundo annuncia.

M achado de Assis faz clamorosa excepção a esta regra. A mulher para elle constitue uma das formulas cabalisticas das sciencias occultas. $N$ as suas praticas a companheira de Adão passa como uma sombra; os desesperos da carne, os transportes da luxuria, os segredos de Poppéa, os filtros de Canídia, não Ihe provocam curiosidades indiscretas, nem referencias que ultrapassem o puro goso litterario.

$O$ vídio pensava assim nas suas $M$ etamorphoses; $C$ atullo foi um grande cultor da arte feminina; Balzac disse taes e taes paradoxos sobre a mulher, e preceituou 0 modo pelo qual os maridos deviam entrar em casa!

Fóra do circulo de observações comedidas como estas, é impossivel obter do auctor do QuincasBorba uma audacia, uma phrase equivoca. Q uando muito, pódese obrigal-o a expôr uma theoria so bre o amor, mas sem sentenças certas e em estylo annuviado. 
D 'ahi a razão pela qual, no seu ultimo livro, Sophia nos apparece, entre Rubião e Carlos M aria, em uma eterna vacillação, que a muito custo se comprehende. E ncarada, substancialmente, essa mulher é uma deshonesta, senão uma descarada: admitte que o marido especule e enriqueça através de sua formosura e á custa do amigo, de quem ella recebe presentes de joias custosíssimas; acceita a côrte de $C$ arlos $M$ aria e adultéra em espirito com elle, esse indifferente; tem ciumes de $M$ aria B enedicta, só porque se falla em casal-a com Rubião; chafurda-se no sensualismo do luxo; sonha grandezas orientaes ; e atira coquettemente convites impossiveis á virilidade indisposta do idiota do herdeiro de Quincas Borba; entretanto, esse idiota, no primeiro accesso de loucura, encerra-se com ella no fundo de uma carruagem, e a depravada, tendo bastante espirito para não arrecear-se do louco, hesita em satisfazer o hausto febricitante do seu erotismo vulgar e complacente.

Tudo isto, porém, encontra explicação nas repugnancias do auctor da obra. $M$ achado de Assisé incapaz de entregar uma heroina sua á logica brutal da respectiva organisação. O nde E. Z ola forçosamente collocaria uma scena de cannibal ismo amoroso e o desespero da burgueza que não soube conter os arrancos da luxuria, elle põe um grito de nobreza e um pudor illogico de mulher perversa e mal casada, cujos transportes domesticos se traduzem ordinariamente em permittir que o esposo ergaIhe o roupão e oscule a perna, no proprio logar em que a meia de seda incide com a carne rósea e assetinada.

$U \mathrm{~m}$ timido - eis o que é nestes assumptos o creador das bellas $M$ emorias de Braz Cubas. Falta-Ihe a afouteza para cheirar o pescoço de M essalina; ferocidade para dilacerar amantes a dentadas, como o poeta Bilac; desprezo á vida para arrostar os perigos dos amores de C leopatra. C ausam-Ihe vertigens as fogueiras voluptuosas do rei Sardanapalo ; não o seduzem as noites de Tigellino, os banquetes de Trimal cião; provocam-Ihe vomitos as orgias de $\mathrm{N}$ ero e as tragedias realistas do Colliseu.

Provoquem-o, porém, para a arena do parodoxo languido do deliquescente do fim do seculo XIX, e vel-o-hão rejuvenescer na ver ve de um cau seur incomparavel.

$E^{\prime}$ possivel que se encontre quem exprima-se com mais vivacidade e elegancia, quem apimente uma anecdota de modo mais dramatico do que elle ; todavía, duvido que um [sic] apresente no Brasil artista mais desvelado no aprumo da conversação e que a tome tão a serio.

M achado de Assis palestrando não galopa no corcel da fantasia doida, como dizem que o fazia o nunca assaz lembrado D umas pai. Faz cousa mais apreciavel quanto a mim; sonha labyrinthos, embrulha-se n'elles; agarra-se a teias de aranhas, dá-Ihes consistencia, doura-as; pendura-se em raios de sol e começa n'estes trapezios delicados a executar uns jogos japonezes que deleitam e prendem a gente por longas horas de recreio.

Estas bizarrices são toda a sua alma de artista, exposta á luz meridiana... dos amigos; d'ellas, isto é, d'esse deposito de ver ve excentrica, timida, nervosa, ás vezes assombradae, é que tal prosador extrahe os personagens, as descripções, e a feição humoristica dos seus melhores livros."

[Texto integral, conforme publicado na Gazeta de $\mathrm{N}$ oticias, do Rio de Janeiro, em duas partes, nos dias 12 e 16 de janeiro de 1892] 


\section{J osé Veríssimo sobre D om Casmurro}

“D om Casmur roé irmão gemeo, posto que com grandes differenças de feições, se não de indole, de Braz Cubas. Eu preferia, e commigo estarão porventura os devotos do escriptor, que a este raro e distincto livro, e a Quincas Borba, que o seguio, differenciando-se por uma humanidade maior e uma realidade mais viva, succedesse uma obra que mostrasse um novo aspecto da imaginação e do pensamento do autor. Relativamente a Braz Cubas, QuincasBorba, derivado, embora, da mesma inspiração, era novo: filho do mesmo sangue, tinha, entretanto, outra phylosophia e outro caracter. Sem ser uma reproducção de Braz C ubas, D om C asmurro tem com elle, mais que o ar da familia dos filhos do mesmo pai, semelhanças do irmão gemeo. São semelhanças, entretanto, que não deixão lugar á confusão. Parecem-se, mas não são os mesmos nem se podem confundir. Se Braz C ubas e D om Casmurro contão ambos os dous a sua historia, cada um tem o seu estylo, a sua lingua, a sua maneira de contar. No que mais se assemelhão é no fundo da sua philosophia e no modo de considerar as cousas. $M$ as ainda assim ha no homem do primeiro reinado e da regencia, que era Braz Cubas, e no homem do segundo imperio, que foi Dom Casmurro, sensiveis differenças de épocas, de civilização, de costumes.

Basta comparar-lhes a linguagem. Certo o estylo é o mesmo. Pois é o estylo de um escriptor feito, e se não muda de estylo como de penna. Só o trocão os que de facto não o têm, e menos poderia reforma-lo um escriptor completo, como o Sr. $M$ achado de Assis, e que o possue com uma individualidade como nenhum outro dosnossos. M as se não é possivel mudar de estylo sem mudar de personalidade, não é impossivel varia-lo, consoante as condições, os generos, os personagens, a indole, a natureza da acção ou da composição da obra litteraria. E esta variação, feita com intelligencia, do Braz C ubaspara o D om C asmurro, bastou para differença-los. N ão faltaria quem inquinasse aquelle de uma linguagem, comquanto de raro sabor artistico e inexcedivel pureza e elegancia, quasi antiquada, com os seus boleios classicos, o uso, embora discreto, de expressões archaicas, a construcção intencionalmente invertida. $\mathrm{N}$ ão vião esses que era um homem, para nós do tempo antigo, espirituoso e douto em letras, que nos recontava a sua historia com a lingua do seu tempo e da sua classe, accrescentada de preoccupações litterarias. Q uem falla em D om C asmurro é outro homem, já do nosso tempo e das nossas idéas, que se formou em S. Paulo e não em Coimbra, e, comquanto pelo espirito, pelo temperamento, apezar da sua casmurrice ulterior e pela concepção da vida, parecido com o outro muito differente delle pelas fórmas e modos com que sentia e se exprimia. Porque na vida, como na arte, que a representa, define ou idealisa, são as fórmas e modos de sentir e de exprimir o que sentimos, mais que o mesmo sentir, que produzem as variedades e differenças da existencia em todos os seus multiplos aspectos. E Dom Casmurro, sentindo talvez, como Braz Cubas, exprime o seu sentimento de outra maneira, que basta para renova-lo e distingui-lo. Braz Cubas, em summa, não dispensa Dom Casmurro, antes de alguma sorte o completa. $M$ as, e aqui venho ao fim do meu reparo, se a critica tem o direito de formular um desejo, eu quizera que, mesmo sem inteirar a trilogia que alguns esperão de Braz Cubas e Quincas Borba, o escriptor 
consummasse a evolução, que porventura neste ultimo se pronnunciava, para um modo mais piedoso, se não mais humano, de conceber a vida e nos désse, como com aquelles dous admiraveis livros, uma obra inteiramente nova. Sabe o Sr. M achado de Assis que taes pedidos se não fazem senão aos opulentos.

A obra litteraria, a obra d'arte, se define pela emoção que deve provocar ou despertar em nós. Essa emoção póde ser sentimental ou intellectual.M esmo de uma emoção puramente sentimental não é possivel excluir, ou sequer abstrahir, a intelligencia, que tem nella a sua funcção propria; mas ha emoções que, sem necessidade dos conceitos da psychologia, cada um de nós sente que nellas predominão já a intelligencia, já o sentimento. E esta predominancia as distingue para nós. Theoricos da esthetica quizerão que o sentimento predominasse sempre nas emo ções artisticas e litterarias. A concepção é, talvez, estreita e acanhadamente comprehensiva, pois uma emo ção intellectual, de ordem esthetica, tende necessariamente a transformar-se em emo ção sentimental, e satisfazer assim os fins que á arte assignão os seus theoristas.

N a obra do Sr. M achado de Assis, a emoção é por via de regra, não sei se não poderia dizer sempre, de ordem intellectual. Fallece-lhe ou esconde-a ciosamente e, talvez, seja esta a hypothese verdadeira - a emoção sentimental. Advirto que não quero fazer a psychologia do Sr. M achado de Assis; e os meus conceitos, certos ou falsos, do escriptor deriva-se apenas do estudo da sua obra. E' notavel que vindo do romantismo, nada Ihe haja ficado do seu sentimentalismo romantico, e que, ao contrario, toda a sentimentalidade, talvez com horror da pieguice em que ella descambou finalmente naquella escola, Ihe repugne profundamente. $M$ as, quando em um escriptor como elle, de uma tão alta honestidade litteraria, sentimos esta especie de repugnancia organica de um tão humano e legitimo sentimento, esta falta desnatural do amor, ao qual devem a arte e a litteratura mais que as suas mais bellas obras, a sua mesma existencia, desperta-se-nos tambem a curiosidade de indagar da sua mesma obra até que ponto será qual se nos figura. D essa obra resumbra uma philoso phia amarga, sceptica, pessimista, uma concepção desencantada da vida, uma desillusão completa dos moveis humanos. E com isto, em vez das imprecações e raivas dos pessimistas profissionais, como os prophetas biblicos, ou seus imitadores hodiernos, a quem uma fé, uma esperança desesperada, uma forte convicção alça a colera ou exaspera a paixão, uma ironia fina, brincalhosa, cortezã de homem bom, mas seguro, como o Eclesiaste, de que tudo é vão neste mundo e resolvido por isso a se não illudir com nenhuma apparencia. N este ultimo rasgo, sente-se no escriptor, se não o esforço, o proposito, como que o timbre, de se não deixar tomar por nescio e ludibriar por cousas que elle assenta fallaciosas. Tudo é vaidade, vão é quanto ha sob o sol. M as, não será tambem vã a ironia, vão o scepticismo, vã a nossa tenção de escaparmos a todas as illusões? Como quer que seja, não escapamos ao encanto amargo desta philosophia desenganada. Se C ohelet buscou palavras deliciosas com que ensina magistralmente as maximas da sua verdade!

$\mathrm{N}$ ão me é possivel rezumir a auto-biographia de D om Casmurro. Se elle não nasceu homem calado e mettido comsigo a vida acabou por faze-lo tal. Sómente aquella philoso phia desabusada, que estava nelle, não consentio que com elle entrasse 
a maldade, permittindo-Ihe apenas a malicia. Q uem foi que disse que a bondade do sceptico é a mais solida?

Não sei se acerto, attribuindo malicia no pobre Bento Santiago, antes que se fizesse Dom Casmurro. N ão, elle era antes ingenuo, simples, candido, confiante, canhestro. O seu mestre - tortuoso e irresistivel mestre! - de desillusões e de enganos, o seu professor, não de melancolia, como outro que inventou o autor de um certo A pologo, mas de alegria e viveza, foi C apitú, a deliciosa Capitú. Foi ella, como dizião as nossas avós, quem o desamou, e, encantadora Eva, quem ensinou a malicia a este novo Adão. Sómente haveria nelle adequadas disposições para receber a agradavel doutrina. Tambem eu duvido que delle sejão as reflexões, as considerações, a luz a que vê as cousas do seu passado. D om Casmurro trahio e calumniou o Bentinho, 0 bom menino, o filho amante, o rapaz innocente e respeitoso, o estudante applicado, o jovem piedoso, o namorado ingenuo, o amigo devotado e confiante, o marido amoroso e credulo. A moral, os commentarios de que acompanha os factos e gestos de Bentinho, são delle, depois que o espirito se lhe desabusou daquelles olhos de Capitú “ que trazião não sei que fluido mysterioso e energico, uma força que arrastava para dentro, como a vaga que se retira da praia, nos dias de ressaca", daquelles "olhos de cigana obliqua e dissimulada" como Ihes chamava, com demasiado estylo, J osé Dias, e tambem dos "olhos dulcissimos" de Escobar, como Ih'os achava mesmo J osé D ias, e da sua polidez, das suas boas maneiras, que a todos captavão. Sim, é de D om Casmurro e não de Bentinho ou sequer de Bento Santiago, o poeta que não é propriamente narrativa da auto-biographia, as reflexões moraes, as explicações dos actos e sentimentos. A única verdadeira e certa das qualidades que se attribuem á mocidade é a illu são com a emoção correspondente. D ecididamente D om C asmurro, de boa ou má fé, calumniou a Bentinho, isto é, a si proprio. Sómente, ditosa culpa, se 0 não houvesse feito, talvez a sua obra, promessa auspiciosa da $\mathrm{H}$ istoria dos Su bu rbi os, que tanta falta está fazendo á nossa historiographia, não tivesse este picante sabor de malicia, nem a novidade com que renovou, difficuldade só dada a vencer aos grandes artistas, um velho thema.

M as tambem, apezar das prevenções de J osé D ias, quem houvera com quinze annos e a innocencia de Bentinho, e mesmo sem isso, resistido á curiosa e solerte Capitú, acoroçoada pela ingenua e velhaca cumplicidade de seus pais? Lê-de-me aquelle delicioso capitulo do «penteado», ó vós que já tivestes quinze annos, e dizeime quem houvera capaz de resistir á Capitú? Bentinho acabára, por um jogo de crianças intimas, de pentear-Ihe os cabellos, e exclama, a obra concluida:

- Prompto!

- Estará bom?

- Veja no espelho.

Em vez de ir ao espelho, que pensas que fez Capitú? N ão vos esqueçais que estava sentada de costas para mim. Capitú derreou a cabeça a tal ponto, que me foi preciso acudir com as mãos e ampara-la; o espaldar da cadeira era baixo. I nclinei-me depois sobre ella, rosto a rosto, mas trocados, os olhos de um na linha da boca do outro. Pedi-lhe que levantasse a cabeça, podia ficar tonta, machucar o pescoço. Cheguei a dizer-Ihe que estava feia ; mas nem esta razão a moveu. 


\section{MACHADO DE ASSIS}

\section{MEMORIAS \\ POSTHUMAS DE \\ B R A Z C UBAS}

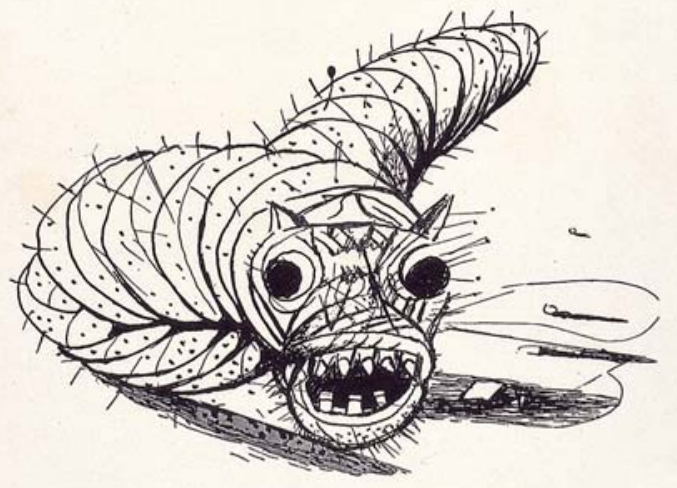

ILUSTRAÇOES DE

CANDIDO PORTINARI

\section{CEM BIBLIÓFILOS DO BRASIL}

Fol ha de rosto de M emórias Póstumas de Brás C ubas. Edição dos C em Bibliófilos do Brasil.

- Levanta, Capitú!

"N ão quiz, não levantou a cabeça, e ficámos assim a olhar um para o outro, até que ella abrochou os labios, eu desci os meus, e..."

Q ue excellente, e penetrante, e fino estudo de mulher nos deu, como a brincar, recobrindo-o de riso e de ironia, o Sr. M achado de Assis, nesta sua Capitú ! E ao 
demais, nova, original, bem nossa, como aliás são, sem embargo da sua real generalidade humana, as creações do Sr. M achado de Assis. Porque, e é seguramente um raro ealto merito, sendo o autor de D om Casmurro o único talvez dos escriptores brazileiros que na ficção se eleva até o geral, o simplesmente humano, sem preoccupação de representações ethnographicas e locaes, nenhum, emtanto, é mais verdadeiro e exacto do que elle quanto [sic] as faz. A extrema flexibilidade do seu talento permitte-Ihe casar perfeitamente a verdade geral e superior da natureza humana, com a verdade particular do temperamento nacional. E esta é, se não me engano, uma das condições da grande arte, do realismo na sua fórma mais elevada e mais pura. A sua litteratura não é de intenção descriptiva; no mundo só Ihe interessa de facto o homem com os seus sentimentos, as suas paixões, os seus moveis de acção; na sua terra, o puro drama, ou comedia, talvez elle preferisse dizer, humano, sem Ihe dar da decoração, da paizagem, dos costumes, do que apenas se servirá para crear aos seus personagens e aos seus feitos o ambiente indispensavel, porque sendo entes vivos não podem viver sem elle.

Entretanto, raros terão, com toda a sua intenção de scenographia, de pintura de costumes, de representação da vida material nos seus aspectos familiares, dado da nossa vida quadros tão acabados, tão vivos. Ainda D om Casmurro é um testemunho de que não erro ou exaggero.

E', talvez, que na obra do Sr. M achado de Assis a representação dos aspectos materiaes da vida não provém da descripção ou da enumeração das partes que os compõem, senão, como nos pintores das novas escolas - e não me refiro ás chamadas decadentes - da impressão geral, e por assim dizer animadas, e quasi espiritual das cousas. N esse sentido elle é, talvez, um ruskiniano: a paizagem, que elle, aliás, não ama, e da qual, que me lembre, jámais se occupou - não será para elle um conjuncto de arvores, montes, aguas, pedras, com este ou aquelle aspecto particular, senão a impressão moral e esthetica que ella produz no artista.

Se esta é, como creio, a caracteristica da sua representação litteraria, tanto nos romances como nos contos, a da sua psychologia é identica a esta, mostrando assim que os seus processos litterarios, como proprios e pessoaes que são, derivão do seu mesmo temperamento de escriptor e procedem de um fundo commum de idéas e sentimentos. Elle não faz a psychologia, nem á moda de Balzac, nem á moda de Burget; sobretudo não a faz á moda deste e de seus imitadores, essa psychologia meticulosa, minuciosa, rebuscada, preciosa como a lingua das sabichonas, e, no fundo falsa. Não a faz, como elles, procurando decompôr uma alma, como se decompõe um corpo em seus elementos constituintes, ou analysar os seus sentimentos como se analysa uma substancia chimica, e explicar os seus moveis como um physiologista explicaria o jogo das funcções do nosso organismo. Sobretudo, elle não a faz com qualquer preoccupação estranha á pura litteratura, ou com os retraços das pretensas psychologias scientificas apanhadas de atro pello em leitura deso rdenada e mal feitas. A sua, certa ou errada, vem evidentemente de uma observação longa, acurada, e aguda. N ão é no geral sympathica, o que póde bem ser Ihe vicie a visão, mas sente-se que é sua. $\mathrm{N}$ ão a expõe em capitulos didacticos; explica-a quanto baste 
para completar a representação que da sua dão os mesmos personagens, mesmas fallas, nos seus gestos, nas suas acções. E ao cabo os seus livros são galerias de gente viva, como este Dom Casmurro, com Capitú, José Dias, Escobar, e as figuras secundarias, os pais de C apitú, D . G loria, J ustina, o tio Cosme. C apitú, a dissimulada, a perfida, é deliciosa de affectuosidade felina, de reflexão e de inconciencia ou displante [sic], de animalidade intelligente e perspicacia feminil, do geito, feitiçaria e graça, e, com isto tudo, viva, real, exacta. D om Casmurro a descreve, aliás, com amor e com odio, o que póde torna-lo suspeito. Elle procura cuidadosamente esconder estes sentimentos, sem talvez consegui-lo de todo. Ao cabo das suas memorias sente-seIhe uma emoção que elle se empenha em refugar. E só. A sua conclusão, que não é talvez aquella que elle confessa, seria acaso que não ha escapar á malicia das mulheres e á má fé dos homens. $M$ as vejo que é no fundo, a mesma que elle nos dá. Perco-me decididamente em explicações. Lêde a fabula, e tirai-Ihe vós mesmos a moralidade."

[T exto integral, conforme publicado no J ornal do Comércio, do Rio de Janeiro, em 19 de março de 1900, com o título "N ovo livro do Sr. M achado de Assis"] 